\title{
Study of the Genetic Diversity of the Ornamental Fish Badis badis (Hamilton-Buchanan, 1822) in the Terai Region of Sub-Himalayan West Bengal, India
}

\author{
Tanmay Mukhopadhyay and Soumen Bhattacharjee \\ Cell and Molecular Biology Laboratory, Department of Zoology, University of North Bengal, P.O. North Bengal University, \\ Raja Rammohunpur, Siliguri, Darjeeling District, West Bengal 734 013, India
}

Correspondence should be addressed to Soumen Bhattacharjee; sbhnbu@gmail.com

Received 27 August 2014; Accepted 9 October 2014; Published 6 November 2014

Academic Editor: Devon Keeney

Copyright (c) 2014 T. Mukhopadhyay and S. Bhattacharjee. This is an open access article distributed under the Creative Commons Attribution License, which permits unrestricted use, distribution, and reproduction in any medium, provided the original work is properly cited.

\begin{abstract}
Dwarf chameleon fish or Badis badis, a lesser known ornamental freshwater fish, has recently been included in the Indian threatened category of fish list. There are insufficient studies with regard to the assessment of genetic background of this ichthyofauna, especially in the western sub-Himalayan region of West Bengal, India, popularly known as the Terai. The present study is the first attempt to investigate the present status of the genetic background of this species in the Mahananda and Balason rivers, major streams of this region. Twenty-one selective RAPD primers generated 53 and 60 polymorphic fragments in the Mahananda and Balason populations, respectively. The proportion of polymorphic loci, Nei's genetic diversity $(H)$, and Shannon's index $\left(H^{\prime}\right)$ were 0.4416 , $0.1654 \pm 0.2023$, and $0.2450 \pm 0.2907$, respectively, in Mahananda river population and were $0.5041,0.1983 \pm 0.2126$, and $0.2901 \pm$ 0.3037, respectively, in Balason river population. Inbreeding coefficient and degree of gene differentiation were also calculated. The $H$ and $H^{\prime}$ were found to be $0.1601 \pm 0.1944$ and $0.2363 \pm 0.2782$, respectively, in overall Mahananda-Balason river system. Our study revealed considerable lack of genetic variation among the individuals of Badis badis. The genetic data obtained from the present study lend support to the view that there is a scope of stock improvement for this ichthyofauna.
\end{abstract}

\section{Introduction}

Badis badis (Hamilton-Buchanan, 1822) (Actinopterygii, Perciformes, Badidae) or dwarf chameleon fish is a tropical, benthopelagic freshwater species that attains up to $5 \mathrm{~cm}$ in total length. It has noteworthy ornamental and thus commercial value and has recently been included within the vulnerable category in the list of threatened freshwater fishes of India by National Bureau of Fish Genetic Resources (NBFGR, Lucknow, India) [1]. However, there have been insufficient studies with regard to the estimation of genetic diversity of this fish species, especially in the eastern sub-Himalayan region of West Bengal, India, popularly known as Terai. The region being included within the Eastern Himalayan hotspot, our results will be important from the standpoint of validation of its threatened status and its conservation/sustainability of wild population, if required.
Genetic variability or diversity is an essential characteristic of any population for the fitness of individuals as well as survival of the whole population, permitting adaptation to the changing environmental conditions and stress. Therefore the degradation of genetic diversity of a species reduces its capability for adaptation and increases the risk of its extinction [2-5]. Inbreeding is implicated in the erosion of genetic variation within natural populations, especially in small populations, by reducing the number of heterozygotes and hence reducing the mean phenotypic values of useful traits [6]. The endangered/vulnerable organisms having small population size may experience a continuous reduction in the level of genetic variation. Therefore, the study of genetic variability is of major importance to conservation, sustainability, and management of wild population which depends on the firsthand knowledge of the amount of variation existing in a local reproductive population [7]. 
PCR-based random amplified polymorphic DNA (RAPD-PCR) is a widely used molecular tool in detection and characterization of genetic polymorphisms in natural populations with higher speed and efficiency [8, 9]. RAPDPCR amplifies DNA segments of variable lengths and such length polymorphisms are inherited in a Mendelian fashion and thus can be used as genetic markers [10]. RAPD analysis has been extensively used to evaluate genetic diversity in Brycon lundii, Astyanax altiparanae and Prochilodus marggravii [11-13], flounder [14], Labeo rohita [15], catfish [16, 17], mud eel [18], ornamental reef fishes [19], crocodile [20], black rat snake [21], and hilsa [22]; and in subspecies identification of tilapia [23], Badis badis, Dario dario [24], and lamprey [25]. A very limited genomic research has been carried out in Badis badis species till date and insufficient genomic information is available to perform other sophisticated fingerprinting techniques where whole genomic sequence is necessary; therefore, RAPD fingerprinting is the best choice for genetic diversity analysis in this species.

The main objectives of our study was to (1) ascertain the present status of the genetic background of the Badis badis species in the Terai region (especially in the Mahananda and Balason river system) of sub-Himalayan Terai region of West Bengal, India, (2) determine the genetic diversity within and between the populations of Badis badis, (3) determine the total genetic diversity of Mahananda-Balason river system of Terai region of sub-Himalayan West Bengal, India. Our results provide firsthand information that may be used in the proper maintenance and conservation of this fish fauna as well as in other dwindled populations.

\section{Materials and Methods}

2.1. Survey and Sample Collection. A detailed survey has been carried out in different spots of the major streams of the Terai region of sub-Himalayan West Bengal, India. A total of twenty samples of Badis badis were collected mainly during the monsoon and after monsoon period from Mahananda and Balason rivers (ten samples from each river system) (Hamilton-Buchanan 1822) during 20122013 and geographic coordinates of the collection spots were recorded with the help of handheld GPS (eTrex Vista $\mathrm{HCx}$, Garmin, USA). Individuals mostly measuring $4 \mathrm{~cm}$ were obtained with the help of a "scoop net" from the submerged vegetation/gravels along the sides of the streams. The collection spots were as follows: in Mahananda River $\left[\mathrm{M} 1=26^{\circ} 42.125^{\prime} \mathrm{N} ; 88^{\circ} 24.717^{\prime} \mathrm{E}\right.$, Elevation-620 ft AMSL and $\mathrm{M} 2=26^{\circ} 44.452^{\prime} \mathrm{N} ; 88^{\circ} 25.497^{\prime} \mathrm{E}$, Elevation-717 ft AMSL]; in Balason River $\left[\mathrm{B} 1=26^{\circ} 43.177^{\prime} \mathrm{N} ; 88^{\circ} 22.825^{\prime} \mathrm{E}\right.$, Elevation$646 \mathrm{ft}$ AMSL and B2 $=26^{\circ} 45.632^{\prime} \mathrm{N} ; 88^{\circ} 18.912^{\prime} \mathrm{E}$, Elevation$731 \mathrm{ft}$ AMSL]; $\mathrm{P}=26^{\circ} 43.007^{\prime} \mathrm{N} ; 88^{\circ} 24.396^{\prime} \mathrm{E}$, Elevation- $666 \mathrm{ft}$ AMSL and $\mathrm{F}=26^{\circ} 38.884^{\prime} \mathrm{N} ; 88^{\circ} 24.125^{\prime} \mathrm{E}$, Elevation- $319 \mathrm{ft}$ AMSL (Figure 1). The M1-M2, B1-B2, P, and F constitute together the whole Mahananda-Balason river system of the Terai region of West Bengal, India. Fishes were identified according to Talwar and Jhingran [26] and were photographed.
2.2. Isolation of High Molecular Weight DNA and Quantification. Genomic DNA (gDNA) extraction was done from tiny amount of tissue samples $(10-15 \mathrm{mg}$ of fin clips from the caudal and ventral portions and/or 25-30 pieces of scales from the dorsal portion were collected noninvasively) from each fish following Mukhopadhyay and Bhattacharjee [27]. The DNA samples were resuspended in $100 \mu \mathrm{L}$ sterile Type1 Milli-Q water and stored at $-20^{\circ} \mathrm{C}$ till further analysis. The extracted DNA samples were subjected to spectrophotometric analysis for quantification in Rayleigh UV2601 Spectrophotometer, Beijing, China, and the concentration of extracted DNA was adjusted to $50 \mathrm{ng} / \mu \mathrm{L}$ after suitable dilution of the extracted DNA samples for each PCR amplification.

2.3. Primer Selection. Forty arbitrary decamer primers of random sequences (Kit-A and Kit-B, twenty primers from each kit) were purchased from Imperial Life Science Pvt. Ltd., India. Twenty-one primers (10 from Kit-A and 11 from Kit-B) were selected for further analyses on the basis of the numbers, variability, and reproducibility of the bands obtained (Table 1).

2.4. RAPD-PCR and Documentation of Amplified Products. RAPD analyses were performed in a 96-well Peltier Thermal Cycler (Applied Biosystems 2720, Life Technologies, USA) in a final reaction volume of $25 \mu \mathrm{L}$, each containing final concentrations of $\sim 100-150 \mathrm{ng}$ of isolated gDNA, $1.6 \mathrm{pM}$ of OPA or OPB primer, 1X Standard Taq Polymerase buffer (10 mM Tris- $\mathrm{HCl}, \mathrm{pH} 8.3,50 \mathrm{mM} \mathrm{KCl}$, and $1.5 \mathrm{mM} \mathrm{MgCl}_{2}$ ) (NEB, USA), $200 \mu \mathrm{M}$ of each of dNTPs (dATP, dTTP, dCTP, and dGTP) (NEB, USA), and one unit of Taq DNA Polymerase (NEB, USA). PCR cycling programs were as follows: initial denaturation at $94^{\circ} \mathrm{C}$ for 5 min followed by 40 cycles of $94^{\circ} \mathrm{C}, 1 \mathrm{~min}$ for denaturation; $35^{\circ} \mathrm{C}, 1 \mathrm{~min}$ for annealing; $72^{\circ} \mathrm{C}, 2 \mathrm{~min}$ for elongation; and finally an extension at $72^{\circ} \mathrm{C}$ for $10 \mathrm{~min}$. The amplified products were electrophoresed in $1.4 \%(\mathrm{w} / \mathrm{v})$ agarose gel (Lonza, Basel, Switzerland) prestained with ethidium bromide $(0.5 \mu \mathrm{g} / \mathrm{mL})$ at a constant voltage $100 \mathrm{~V}$ and current $100 \mathrm{~mA}$ in TAE buffer $(40 \mathrm{mM}$ Tris- $\mathrm{HCl}, \mathrm{pH}$ 8.0; $20 \mathrm{mM}$ acetic acid; and $1 \mathrm{mM}$ EDTA, $\mathrm{pH}$ 8.0) using BenchTop Labsystems BT-MS-300, Taiwan electrophoretic apparatus. Molecular weight of each band was estimated using a standard 100 base pair ladder (NEB, USA) and/or Lambda EcoRI/HindIII double digest DNA size marker (NEB, USA). The gels were visualized on the UV-transilluminator (Spectroline BI-O-Vision NY, USA) and photographed using a digital camera.

2.5. RAPD Data Analyses. RAPD data were analyzed for assessing within and between populations genetic variability of Badis badis in the two major rivers. The RAPD marker profiles were determined by direct comparison of the amplified profiles and the data obtained were computed and analyzed in the form of binary variables $(1=$ band present or $0=$ band absent). Each locus was treated as a two-allele system, where only one of the alleles per locus was amplifiable by PCR and each fragment represented a Mendelian locus in which the 


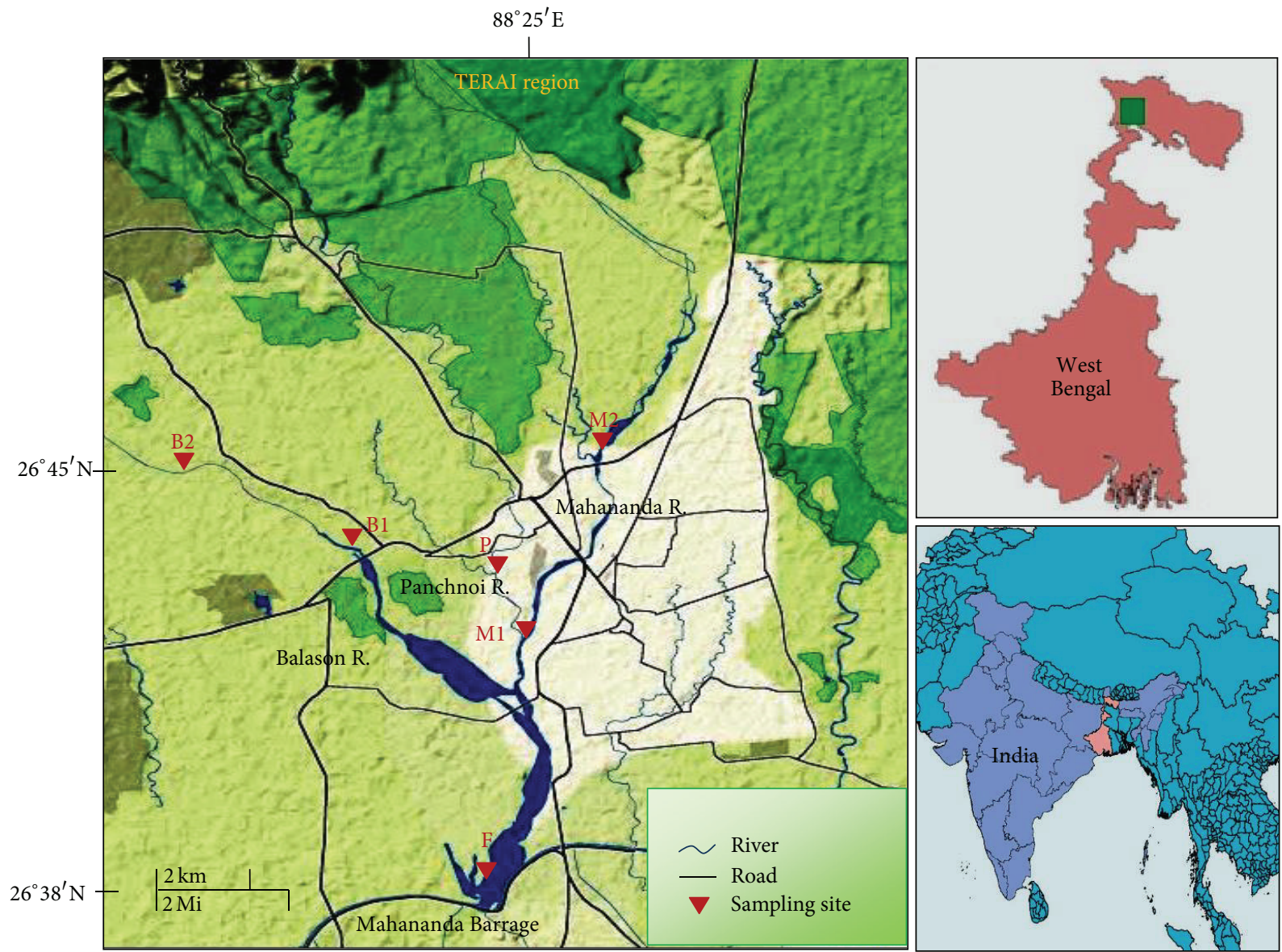

FIGURE 1: Map showing collection spots of Badis badis from the major streams of the Terai region of West Bengal, India. Geographical coordinates and altitudes, recorded by hand-held Garmin eTrex Vista HCx GPS, are as follows: M1 = 26 $42.125^{\prime} \mathrm{N} ; 88^{\circ} 24.717^{\prime} \mathrm{E}$; $620 \mathrm{ft}$ AMSL; $\mathrm{M} 2=26^{\circ} 44.452^{\prime} \mathrm{N} ; 88^{\circ} 25.497^{\prime} \mathrm{E} ; 717 \mathrm{ft}$ AMSL; B1 $=26^{\circ} 43.177^{\prime} \mathrm{N} ; 88^{\circ} 22.825^{\prime} \mathrm{E} ; 646 \mathrm{ft}$ AMSL and B2 $=26^{\circ} 45.632^{\prime} \mathrm{N} ; 88^{\circ} 18.912^{\prime} \mathrm{E} ; 731 \mathrm{ft}$ AMSL, P $=26^{\circ} 43.007^{\prime} \mathrm{N} ; 88^{\circ} 24.396^{\prime} \mathrm{E} ; 666 \mathrm{ft}$ AMSL and $\mathrm{F}=26^{\circ} 38.884^{\prime} \mathrm{N} ; 88^{\circ} 24.125^{\prime} \mathrm{E} ; 319 \mathrm{ft}$ AMSL.

visible "dominant" allele was in Hardy-Weinberg equilibrium (HWE) with the corresponding "recessive" null allele or the absent fragment $[9,28]$. The binary scores obtained from all the twenty-one primers in the RAPD analyses were then pooled for constructing a single data matrix for further analysis. Each set of PCR was repeated for at least three times to check the reproducibility of the banding pattern generated.

The RAPD data was analysed using three software applications, namely, Popgene ver. 1.32 [29], TFPGA (Tools for Population Genetic Analysis) ver. 1.3 [30], and GenAlEx 6.5 $[31,32]$. Total number of RAPD bands, monomorphic bands, and polymorphic bands within and between populations were calculated manually by directly scoring the RAPD amplified banding profiles from gel photographs. Different indices of diversity measurement were used for assessing the genetic background of Badis badis species. The data matrix was used to estimate the observed number of alleles $\left[(1 / K) \sum n_{i}\right.$, where $K$ is the number of loci and $n_{i}$ is the number of alleles detected per locus], effective number of alleles $\left(1 / \sum p_{i}^{2}\right.$, where $p_{i}$ is frequency of particular RAPD band) [33], number of polymorphic loci, proportion of polymorphic loci, Nei's genetic diversity $(H)$ [34], and Shannon's information index $\left(H^{\prime}\right.$ or $I=-\sum p_{i} \log 2 p_{i}$, where $H^{\prime}$ or $I$ is diversity and $p_{i}$ is the frequency of a particular RAPD band) [35]. The rates of polymorphism were calculated using the criterion for polymorphism in which the frequency of the most common allele was $\leq 0.95$ or $\leq 0.99$. The maximum diversity has been found where all RAPD bands had equal abundance. For better interpretation of Shannon's information index we have used the exponential function of Shannon's index, that is, $e^{H^{\prime}}$, and subsequently calculated the measures of evenness $\left(E=e^{H^{\prime}} / S\right.$, where $S$ is the observed number of alleles). The proportion of total inbreeding within the population was assessed by the formula $F_{I S}=F_{I T}-F_{S T} / 1-F_{S T}$ (where $F_{I S}$ is the measure of inbreeding or departure from Hardy-Weinberg (HW) proportions within local demes or subpopulations, $F_{S T}$ is the measure of allele frequency divergence among subpopulations relative to metapopulation, and $F_{I T}$ is the measure of the overall departure from HW proportions for individuals with the metapopulation) [36].

To analyze the population genetic differentiation of Badis badis, $F_{S T}$ values were calculated using the formula $F_{S T}=$ $1-H_{S} / H_{T}$ (where $H_{S}$ is the average expected heterozygosity estimated from each subpopulation and $H_{T}$ is the total gene diversity or expected heterozygosity in the total population 
TABLE 1: Code and sequence of random primers used for detection of polymorphism in B. badis populations.

\begin{tabular}{|c|c|c|c|}
\hline Sl/No. & Primer & Sequence $\left(5^{\prime} \rightarrow 3^{\prime}\right)$ & $\mathrm{G}+\mathrm{C}$ Content $(\%)$ \\
\hline 1 & OPA-01 & CAGGCCCTTC & 70 \\
\hline 2 & OPA-02 & TGCCGAGCTG & 70 \\
\hline 3 & OPA-04 & AATCGGGCTG & 60 \\
\hline 4 & OPA-07 & GAAACGGGTG & 60 \\
\hline 5 & OPA-09 & GGGTAACGCC & 70 \\
\hline 6 & OPA-10 & GTGATCGCAG & 60 \\
\hline 7 & OPA-13 & CAGCACCCAC & 70 \\
\hline 8 & OPA-16 & AGCCAGCGAA & 60 \\
\hline 9 & OPA-19 & CAAACGTCGG & 60 \\
\hline 10 & OPA-20 & GTTGCGATCC & 60 \\
\hline 11 & OPB-01 & GTTTCGCTCC & 60 \\
\hline 12 & OPB-03 & CATCCCССТG & 70 \\
\hline 13 & OPB-04 & GGACTGGAGT & 60 \\
\hline 14 & OPB-05 & TGCGCCCTTC & 70 \\
\hline 15 & OPB-06 & TGCTCTGCCC & 70 \\
\hline 16 & OPB-07 & GGTGACGCAG & 70 \\
\hline 17 & OPB-11 & GTAGACCCGT & 60 \\
\hline 18 & OPB-12 & CCTTGACGCA & 60 \\
\hline 19 & OPB-13 & TTCCCCCGCT & 70 \\
\hline 20 & OPB-17 & AGGGAACGAG & 60 \\
\hline 21 & OPB-18 & CCACAGCAGT & 60 \\
\hline
\end{tabular}

as estimated from the pooled allele frequencies) [36]. The diversity among populations $\left(D_{S T}=H_{T}-H_{S}\right)$ was also calculated to ascertain the interpopulation diversity between different pairwise populations.

\section{Results}

RAPD data were analyzed to ascertain within and between populations genetic variability as well as genetic differences within and between the Badis badis populations of two major river streams of the Terai region of West Bengal India. The banding patterns generated through RAPD assay in the present study were used to evaluate the genetic variation within and between the populations of $B$. badis from the two major rivers of Terai region.

3.1. RAPD Profile. Twenty-one RAPD primers generated in total 120 (average 5.71) bands in M1-M2 population and 121 (average 5.76) bands in B1-B2 population (Figure 2). The number of bands ranged from 9 (OPA16, OPB04, and OPB17) to 3 (OPB11 and OPB18) in M1-M2 population and from 9 (OPB04) to 3 (OPB18) in B1-B2 population, respectively, (Table 2). The number of monomorphic bands ranged from 5 (OPA01, OPB04, and OPB06) to 1 (OPB03) in M1-M2 population and from 5 (OPA13 and OPB01) to 0 (OPB03 and OPB13) in B1-B2 population, respectively, (Table 2). The number of polymorphic bands ranged from 6 (OPB17) to 0 (OPB18) in M1-M2 population and from 5 (OPB17) to 0 (OPA13 and OPB18) in B1-B2 population, respectively, (Table 2). The total number of bands, monomorphic bands, and polymorphic bands obtained between the M1-M2 population and the B1$\mathrm{B} 2$ population ranged from 10 (OPB13) to 3 (OPB18), from 6 (OPA01) to 0 (OPB03 and OPB13), and from 9 (OPB12) to 1 (OPA10, OPA13, and OPB18), respectively, (Table 2).

3.2. Within Population Diversity. The total number of monomorphic and polymorphic bands generated after amplification with twenty-one RAPD primers in M1-M2 population was 67 (average 3.19) and 53 (average 2.52), respectively, (Table 2). The total number of monomorphic and polymorphic bands generated in B1-B2 population was 61 (average 2.90) and 60 (average 2.86), respectively, (Table 2). Diversity and evenness indices were estimated in the two Badis badis populations separately (Table 3 ). The richness or observed number of alleles and effective number of alleles of M1-M2 population were $1.4500 \pm 0.4996$ and $1.2863 \pm 0.3797$, respectively. The proportion of polymorphic loci was $0.4416(44.16 \%)$. The Nei's genetic diversity $(H)$ and Shannon's information index $\left(H^{\prime}\right.$ or $\left.I\right)$ were $0.1654 \pm$ 0.2023 and $0.2450 \pm 0.2907$, respectively. The richness or observed number of alleles and effective number of alleles of B1-B2 population were $1.5041 \pm 0.5021$ and $1.3501 \pm$ 0.3946 , respectively. The proportion of polymorphic loci was $0.5041(50.41 \%)$. The Nei's genetic diversity $(H)$ and Shannon's information index $\left(H^{\prime}\right.$ or $\left.I\right)$ were $0.1983 \pm 0.2126$ and $0.2901 \pm 0.3037$, respectively. The measure of evenness (E) was 0.8811 and 0.8886 in M1-M2 and B1-B2 populations, respectively. The inbreeding coefficient $\left(F_{I S}\right)$ of M1-M2 and B1-B2 populations was 0.1387 and 0.1316 , respectively (Table 3). 


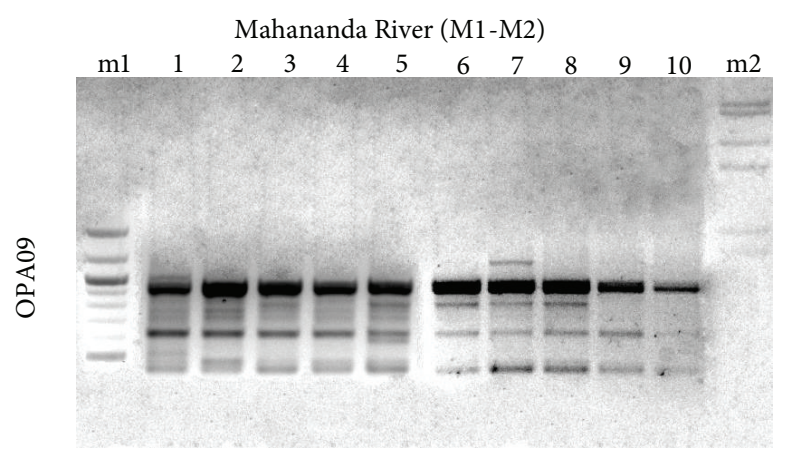

(a)

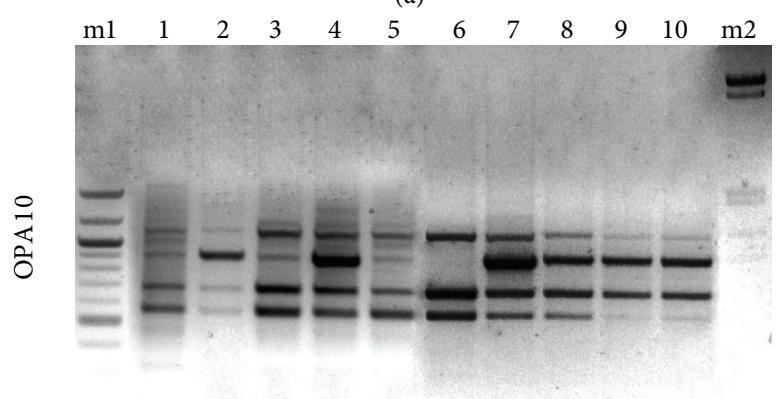

(b)

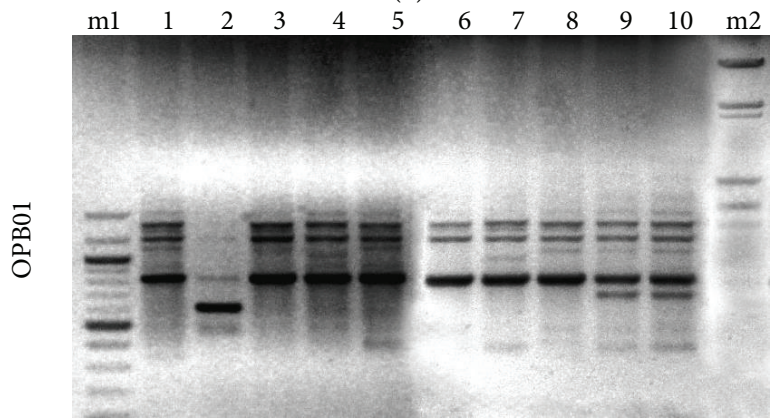

(c)

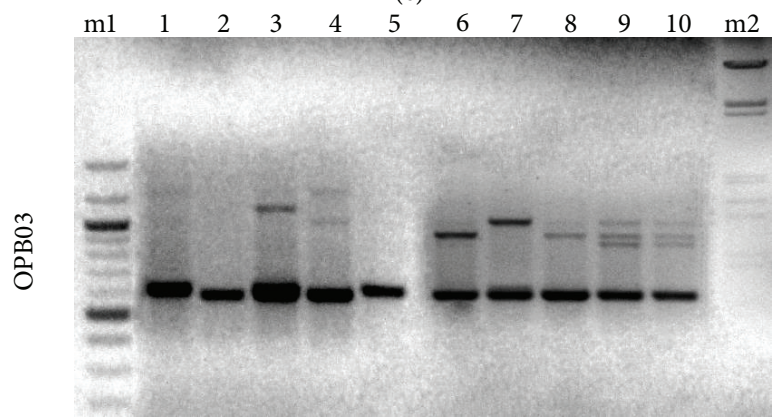

(d)

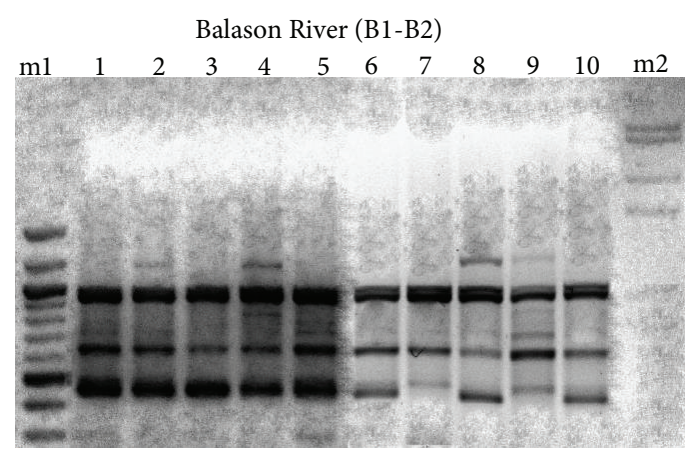

(e)

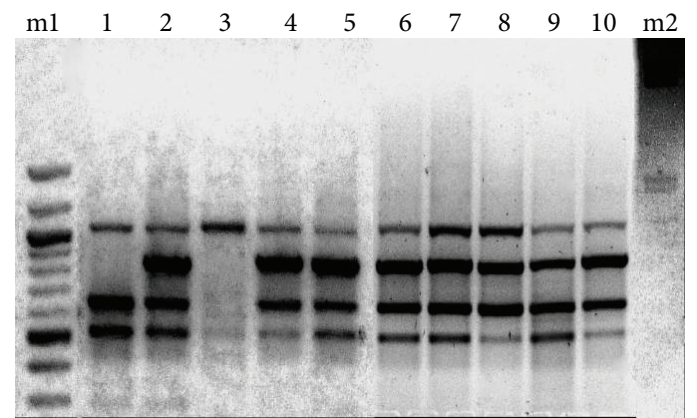

(f)

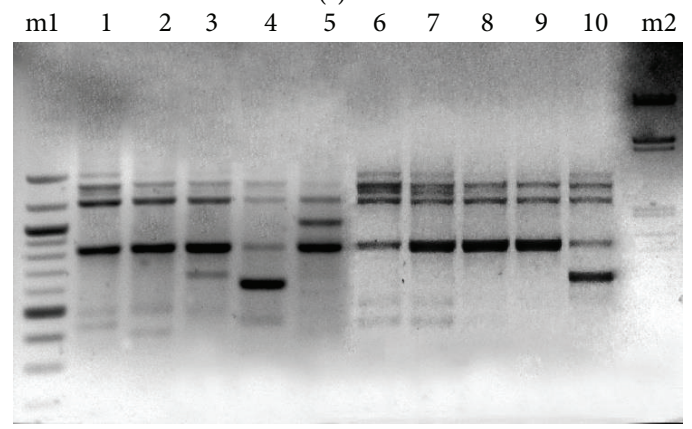

(g)

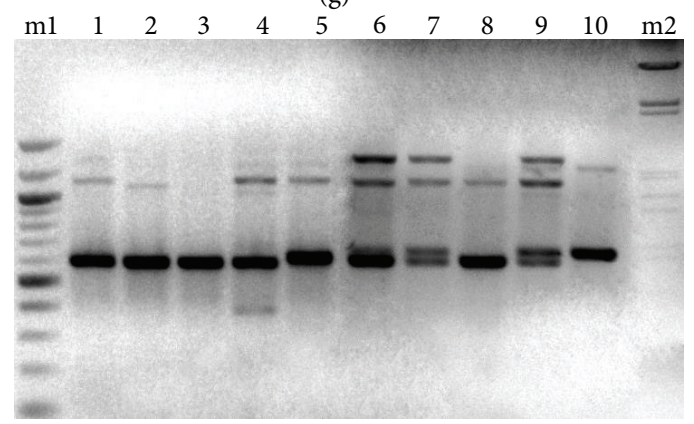

(h)

FIGURE 2: Representative $1.4 \%$ agarose gel showing RAPD fragment patterns generated using OPA09, 10 and OPB01, 03 primers from Mahananda (M1 and M2) (a) to (d) and Balason river populations (B1 and B2) (e) to (h). m1: 100 base pair DNA ladder; m2: Lambda DNA EcoRI/HindIII double digest. Lanes 1 to 10 indicate 10 individuals from each river populations

3.3. Between Population Diversity and Genetic Differentiation. The total number of RAPD fragments scored between the Mahananda (M1-M2) and the Balason (B1-B2) populations was 150 (average 7.14) and the number of monomorphic and polymorphic bands scored was 49 (average 2.33) and 101 (average 4.81), respectively, (Table 2). The richness or observed number of alleles and effective number of alleles of among the Mahananda and Balason populations were $1.6733 \pm 0.4706$ and $1.3752 \pm 0.3642$, respectively, (Table 3 ). The proportion of polymorphic loci was $0.6733(67.33 \%)$ (Table 3$)$. The Nei's genetic diversity $(H)$ and Shannon's information index $\left(H^{\prime}\right.$ or $\left.I\right)$ were $0.2228 \pm 0.1934$ and 0.3364 
TABLE 2: RAPD band profiles for the twenty-one primers in Badis badis population from two different locations of the Terai region of West Bengal.

\begin{tabular}{|c|c|c|c|c|c|c|c|c|c|}
\hline \multirow[b]{3}{*}{ Primers } & \multicolumn{9}{|c|}{ Populations } \\
\hline & \multicolumn{3}{|c|}{ "M1-M2" } & \multicolumn{3}{|c|}{ “B1-B2” } & \multicolumn{3}{|c|}{ "Between M1-M2 and B1-B2" } \\
\hline & $\begin{array}{c}\text { Total } \\
\text { number of } \\
\text { bands }\end{array}$ & $\begin{array}{c}\text { Total } \\
\text { number of } \\
\text { monomor- } \\
\text { phic } \\
\text { bands }\end{array}$ & $\begin{array}{c}\text { Total } \\
\text { number of } \\
\text { polymor- } \\
\text { phic } \\
\text { bands }\end{array}$ & $\begin{array}{c}\text { Total } \\
\text { number of } \\
\text { bands }\end{array}$ & $\begin{array}{c}\text { Total } \\
\text { number of } \\
\text { monomor- } \\
\text { phic } \\
\text { bands }\end{array}$ & $\begin{array}{c}\text { Total } \\
\text { number of } \\
\text { polymor- } \\
\text { phic } \\
\text { bands }\end{array}$ & $\begin{array}{c}\text { Total } \\
\text { number of } \\
\text { bands }\end{array}$ & $\begin{array}{c}\text { Total } \\
\text { number of } \\
\text { monomor- } \\
\text { phic } \\
\text { bands }\end{array}$ & $\begin{array}{c}\text { Total } \\
\text { number of } \\
\text { polymor- } \\
\text { phic } \\
\text { bands }\end{array}$ \\
\hline OPA-01 & 8 & 5 & 3 & 8 & 4 & 4 & 9 & 6 & 3 \\
\hline OPA-02 & 5 & 3 & 2 & 6 & 2 & 4 & 7 & 3 & 4 \\
\hline OPA- 04 & 5 & 3 & 2 & 5 & 2 & 3 & 7 & 3 & 4 \\
\hline OPA- 07 & 7 & 3 & 4 & 5 & 3 & 2 & 7 & 2 & 5 \\
\hline OPA-09 & 5 & 3 & 2 & 6 & 4 & 2 & 6 & 3 & 3 \\
\hline OPA-10 & 4 & 3 & 1 & 4 & 1 & 3 & 5 & 4 & 1 \\
\hline OPA-13 & 6 & 4 & 2 & 5 & 5 & 0 & 6 & 5 & 1 \\
\hline OPA-16 & 9 & 4 & 5 & 5 & 4 & 1 & 9 & 2 & 7 \\
\hline OPA-19 & 5 & 2 & 3 & 5 & 2 & 3 & 8 & 2 & 6 \\
\hline OPA-20 & 7 & 3 & 4 & 6 & 2 & 4 & 8 & 3 & 5 \\
\hline OPB-01 & 4 & 1 & 3 & 7 & 5 & 2 & 8 & 1 & 7 \\
\hline OPB-03 & 4 & 1 & 3 & 4 & 0 & 4 & 5 & 0 & 5 \\
\hline OPB-04 & 5 & 5 & 0 & 9 & 5 & 4 & 9 & 2 & 7 \\
\hline OPB-05 & 6 & 4 & 2 & 8 & 4 & 4 & 8 & 3 & 5 \\
\hline OPB-06 & 5 & 5 & 0 & 5 & 3 & 2 & 6 & 3 & 3 \\
\hline OPB-07 & 9 & 4 & 5 & 7 & 3 & 4 & 9 & 1 & 8 \\
\hline OPB-11 & 3 & 2 & 1 & 5 & 2 & 3 & 6 & 1 & 5 \\
\hline OPB-12 & 7 & 4 & 3 & 6 & 4 & 2 & 10 & 1 & 9 \\
\hline OPB-13 & 4 & 2 & 2 & 4 & 0 & 4 & 5 & 0 & 5 \\
\hline OPB-17 & 9 & 3 & 6 & 8 & 3 & 5 & 9 & 2 & 7 \\
\hline OPB-18 & 3 & 3 & 0 & 3 & 3 & 0 & 3 & 2 & 1 \\
\hline Total & 120 & 67 & 53 & 121 & 61 & 60 & 150 & 49 & 101 \\
\hline Average & 5.71 & 3.19 & 2.52 & 5.76 & 2.90 & 2.86 & 7.14 & 2.33 & 4.81 \\
\hline
\end{tabular}

$\mathrm{M} 1$ and M2 sites are from Mahananda river; B1 and B2 sites are from Balason river.

TABLE 3: Within and between populations genetic diversity, evenness, and inbreeding coefficient of B. badis based on RAPD analyses.

\begin{tabular}{|c|c|c|c|c|c|c|c|}
\hline Population name & $S( \pm \mathrm{SD})$ & $\begin{array}{l}\text { Effective number } \\
\text { of alleles }( \pm S D)\end{array}$ & $\begin{array}{c}\text { Proportion of } \\
\text { polymorphic loci }\end{array}$ & $H( \pm \mathrm{SD})$ & $H^{\prime}$ or $I( \pm \mathrm{SD})$ & $E=e^{H^{\prime}} / S$ & $F_{I S}$ \\
\hline M1/M2 & $1.4500 \pm 0.4996$ & $1.2863 \pm 0.3697$ & $0.4416(44.16 \%)$ & $0.1654 \pm 0.2023$ & $0.2450 \pm 0.2907$ & 0.8811 & 0.1387 \\
\hline B1/B2 & $1.5041 \pm 0.5021$ & $1.3502 \pm 0.3946$ & $0.5041(50.41 \%)$ & $0.1983 \pm 0.2126$ & $0.2901 \pm 0.3037$ & 0.8886 & 0.1316 \\
\hline $\mathrm{M} 1 / \mathrm{M} 2$ and $\mathrm{B} 1 / \mathrm{B} 2$ & $1.6733 \pm 0.4706$ & $1.3752 \pm 0.3642$ & $0.6733(67.33 \%)$ & $0.2228 \pm 0.1934$ & $0.3364 \pm 0.2747$ & 0.8360 & 0.1290 \\
\hline $\begin{array}{l}\text { Mahananda- } \\
\text { Balason river } \\
\text { system }\end{array}$ & $1.4372 \pm 0.4680$ & $1.2894 \pm 0.3724$ & $0.4371(43.71 \%)$ & $0.1601 \pm 0.1944$ & $0.2363 \pm 0.2782$ & 0.8876 & 0.0884 \\
\hline
\end{tabular}

$S:$ Observed number of alleles or richness; $H$ : Nei's gene diversity; $H^{\prime}$ or $I:$ Shannon's information index; $E$ : measure of evenness; $F_{I S}=F_{I T}-F_{S T} / 1-F_{S T}=$ Inbreeding coefficient.

\pm 0.2747 , respectively. The measure of evenness $(E)$ was 0.8360 (Table 3$)$. The expected $\left(H_{T}\right)$ and mean heterozygosity $\left(H_{S}\right)$, diversity among populations $\left(D_{S T}\right)$, and degree of gene differentiation $\left(F_{S T}\right)$ were estimated between Mahananda and Balason populations. The expected and mean heterozygosity were found to be $0.2228 \pm 0.0374$ and $0.1758 \pm 0.0289$, respectively, (Table 4). The diversity among the Mahananda and Balason populations was 0.0470 (Table 4). The degree of gene differentiation between the Mahananda and Balason populations was calculated to be 0.2109 (Table 4 ). The inbreeding coefficient $\left(F_{I S}\right)$ between populations was found to be 0.1290 (Table 3). 
TABLE 4: Between populations diversity and gene differentiation in two different populations of $B$. badis based on RAPD analyses.

\begin{tabular}{lcccc}
\hline Populations & $H_{T}$ & $H_{S}$ & $D_{S T}$ & $F_{S T}$ \\
\hline $\begin{array}{l}\text { Mahananda } \\
\text { (M1/M2) and }\end{array}$ & $0.2228 \pm 0.0374$ & $0.1758 \pm 0.0289$ & 0.0470 & 0.2109 \\
$\begin{array}{l}\text { Balason } \\
\text { (B1//B2) }\end{array}$ & & & & \\
\hline
\end{tabular}

$H_{T}$ : expected heterozygosity in random mating total population; $H_{S}$ : mean expected heterozygosity within random mating subpopulations; $D_{S T}$ : diversity among populations; $F_{S T}$ : degree of gene differentiation among populations in terms of allele frequencies.

\subsection{Total Genetic Diversity of Mahananda-Balason River Sys-} tem. The observed number of alleles (richness) and effective number of alleles of the Mahananda-Balason river system (combining all the sites, namely, M1-M2, B1-B2, P, and F) were found to be $1.4372 \pm 0.4680$ and $1.2894 \pm 0.3724$, respectively, (Table 3 ). The proportion of polymorphic loci was 0.4371 (43.71\%) (Table 3 ). The Nei's genetic diversity $(H)$ and Shannon's information index $\left(H^{\prime}\right.$ or $\left.I\right)$ were $0.1601 \pm$ 0.1944 and $0.2363 \pm 0.2782$, respectively. The measure of evenness $(E)$ was 0.8876 . The inbreeding coefficient $\left(F_{I S}\right)$ of the whole river system population was calculated to be 0.0884 (Table 3).

\section{Discussion}

RAPD-PCR can be used as an efficient molecular tool to differentiate allopatrically and/or sympatrically isolated populations and has been widely used to delineate the available gene pool of locally adapted populations of a species that may have arisen either by means of genetic selection under different environmental pressure or as a result of genetic drift [37]. To our knowledge, the present study is the first attempt to explore the present status of population specific genetic background of this fish fauna in the major river streams in the Terai region of this sub-Himalayan hotspot of North Eastern India. Our results showed that there is considerable lack of genetic variation among populations of Badis badis collected from the Mahananda-Balason river system.

Forty decamer primers were initially used to screen two different populations, and twenty-one primers were finally chosen for the study based on reproducibility of banding patterns (Table 1). The obtained results showed that the analyzed decamer primers permitted the detection of polymorphic fragments in Badis badis, revealing lower levels of genetic variability within and between two populations of major river streams of the study region. In the present study the number of amplified fragments generated by primer OPB12 was 6$10,8-9$ by primer OPB17, and 3 by primer OPB18, which were comparable with the amplified fragments observed by Brahmane et al. [24] (OPB12 = 4-6 bands, OPB17 = 3-6 bands, and OPB18 = 3-4 bands) in Badis badis populations collected from three districts of West Bengal namely, Nadia, North 24 Parganas, and Coochbehar. While there is an absence of comparable data on Badis badis and other related species from other Indian rivers, we have compared our results with some evolutionary related species as well as some vulnerable species found in geographically related areas. In a study carried out by Kader et al. [38] on three Tilapia species (Oreochromis niloticus, O. aureus, and Tilapia zilli) in Egypt and by Chandra et al. [39] on vulnerable Eutropiichthys vacha in India, 15 RAPD primers generated 201 and 45 polymorphic amplified fragments, respectively. In a different study carried out by Alam et al. [18] and Miah et al. [40] on another locally vulnerable species of Mud eel (Monopterus cuchia) in Bangladesh, the number of polymorphic bands generated were 30 out of 39 bands and 24 out of 73 bands, respectively. Another study on endemic catfish (Horabagrus brachysoma) in the Western Ghat region of South India and the Clarias batrachus in Indian riverine system reported the number of polymorphic bands to be 75 and 358 , respectively $[41,42]$. The difference in the number and sizes of the amplified fragments can be ascribed to the sequence of the primers used and the source of the template DNA when compared to comparable studies. We have chosen a large number of decamer primers to provide robustness to our results [43].

The possible reason behind the observed high between populations allelic richness may be ascribed to the spatial distribution of the two populations (Figure 1). In a study on three Tilapia species in Egypt, the proportion of polymorphic loci was $51.8 \%, 58.6 \%$, and $60.3 \%$, respectively [38] and the proportion of polymorphic lociof Tilapia zilli and Oreochromis niloticus populations in Lake Victoria of Africa was $65.0 \%$ and $59.0 \%$, respectively [44]. In the studies on vulnerable Mud eel of Bangladesh, the proportion of polymorphic loci was $76.92 \%$ [18] and $32.87 \%$ [40], while in the studies on endemic yellow catfish Horabagrus brachysoma and Clarias batrachus the proportion of polymorphic loci was $60.48 \%$ [41] and $77.49 \%$ [42], respectively. In the present study the proportion of polymorphic loci varies from 0.4371 (43.71\%) in overall population to $0.6733(67.33 \%)$ in between populations (Table 3 ). The overall proportion of polymorphic loci $(43.71 \%)$ is lower than that found in phylogenetically related and vulnerable fish fauna indicating a substantial decline of genetic variability within Badis badis population of the sub-Himalayan Terai region.

Our study revealed that the Nei's genetic diversity $(H)$ within the Mahananda (M1-M2) and Balason (B1-B2) populations is 0.1654 and 0.1983 , respectively, whereas genetic diversity between populations is 0.2228 (Table 3 ). The overall genetic diversity of the river system was 0.1601 (Table 3 ). An earlier study carried out by Mwanja et al. [44] on Oreochromis niloticus populations in eastern Africa revealed that the genetic diversity ranged from highest (Lake Kachira $=0.27$ and Lake Nabugabo $=0.29)$ to intermediate (Lake Albert $=$ 0.17 and Lake Victoria $=0.20$ ) and to lowest (Lake Edward $=0.14)$ values. The studies carried out by Appleyard and Mather [45] in Oreochromis mossambicus populations in Fiji islands displayed a lower ( 0.091 to 0.111$)$ to highest $(0.165$ to 0.187 ) levels of observed heterozygosity. Moreover, Kader et al. [38] found that the genetic diversity was higher in Tilapia zilli(0.249) than in the O. niloticus and O. aureus populations $(0.219$ and 0.238 , resp.). In the study carried out on vulnerable Monopterus cuchia in Bangladesh and on endemic species Horabagrus brachysoma in India [41] Nei's genetic diversity 
was 0.285 and 0.222 , respectively. Therefore in comparison it can be said that genetic diversity of Badis badis population in the Mahananda-Balason river system ranges from lower to intermediate values.

In our study the Shannon's information index $\left(H^{\prime}\right)$ was calculated to be $0.240 \pm 0.2907$ in Mahananda (M1-M2), $0.2901 \pm 0.3037$ in Balason (B1-B2), and $0.3364 \pm 0.2747$ in Mahananda-Balason taken together, respectively, whereas the $H^{\prime}$ of overall river system was $0.2363 \pm 0.2782$ (Table 3 ). These results are similar to the findings of Chandra et al. [39] on Eutropiichthys vacha, where the Shannon's index was 0.280 and 0.300 in Patnaand Madhepura populations, respectively. Moreover, Kader et al. [38] reported that Tilapia zilli population had a higher proportion of heterozygous genotypes $\left(H^{\prime}=0.363\right)$ than $O$. niloticus $\left(H^{\prime}=0.318\right)$ and O. aureus populations $\left(H^{\prime}=0.347\right)$. In two different studies carried out by Alam et al. [18] and Miah et al. [40] on mud eel Monopterus cuchia in Bangladesh, the Shannon's information index was 0.423 and 0.213 , respectively. Comparing our data with that of Oreochromis sp. and Eutropiichthys vacha it was found that the genetic diversity of Badis badis in the major river streams (Mahananda and Balason) of Terai region is lower.

We have used this exponential function of Shannon's index (i.e., $e^{H^{\prime}}$ ) to calculate the measure of evenness [46]. The measure of evenness was more or less similar in these two populations: 0.8811 in Mahananda population and 0.8886 in Balason population (Table 3 ). Therefore, this indicates that the gene pool of these two populations is genetically quite even in distribution. This might happen as an outcome of addition of juveniles due to the joining of the major streams with small tributaries, especially during the monsoonal breeding season, which may result in substantial amount of gene flow between these two major river stream populations.

While the value of $F_{I S}$ ranged from -1.0 (all the individuals within a subpopulation being heterozygotes) to +1.0 (no observed heterozygotes are present within a subpopulation), we have found that the Mahananda and Balason river system showed positive values of the inbreeding coefficient [Mahananda population (M1-M2) $=0.1387$, Balason population $(\mathrm{B} 1-\mathrm{B} 2)=0.1316$, between Mahananda and Balason population (M1-M2 and B1-B2) = 0.1290; and 0.0884 in the overall Mahananda-Balason river system] indicated a lower number of heterozygotes within these two populations. Abdul Muneer et al. [41] also reported that the $F_{I S}$ value of Horabagrus brachysoma was 0.504 indicating a deficiency of heterozygotes. Nonrandom mating or inbreeding, spatial Wahlund effect, and expression of null alleles are the leading causes of heterozygotes deficiency in small populations. However, in small populations sexual differences in allele frequencies are likely to cause an increase in heterozygotes relative to Hardy-Weinberg proportions and therefore there is a tendency for the excessof heterozygotes [47].

Fixation index or $F_{S T}$ is a measure of genetic divergence among subpopulations that ranges from 0 (when all subpopulations have equal allele frequencies) to 1 (when all the subpopulations are fixed for different alleles) [47]. We have found that between the Mahananda and Balason populations the $D_{S T}$ value was 0.047 and the $F_{S T}$ value was 0.2109 (Table 4). In a different study carried out by Abdul Muneer et al. [41] on Horabagrus brachysoma the $F_{S T}$ value ranged from the maximum (0.219) between (0.045) Meenachil and Nethravathi populations to the minimum between $(0.045)$ Meenachil and Chalakkudi populations. The lower value of $D_{S T}$ in the present study indicates that the diversity between these two populations was low and a higher $F_{S T}$ value indicates that gene differentiation was high. The observed $D_{S T}$ and $F_{S T}$ values may be attributed to several factors, namely, lack of migration, lower level of gene flow, water flow pattern, water volume, fishing extent, and other possible anthropogenic and/or geological activities. This decrease in genetic diversity and variability within and between the gene pools of the Badis population in the study area may result due to flow pattern disturbances owing to sand/stone excavation, indiscriminate fishing and pesticide run-offs from adjacent tea gardens in the hilly areas of lower Himalayas, as the river streams flow from higher to lower altitudes. All of these causes can culminate into the observed lower level of the genetic diversity pattern and genetic erosion in Badis badis populations across the Mahananda and Balason river system.

However there was a weak point in this study, as a limited number of (ten samples from each river stream) individuals were involved for genetic analyses, primarily because of the dwindling population structure of the species and also to have ease in data handling and analyses. However a large number of decamer primers were used to provide robustness to the study. The present study using twenty-one RAPD primers revealed that a lower level of genetic diversity exists in the Badis badis populationof the Mahananda-Balason river system in the Terai region. Several anthropogenic interferences like indiscriminate fishing, effluents from adjacent households and factories, heavy use of fertilizers and pesticides in the nearby tea gardens and their subsequent run-offs into the hilly parts of the streams, or excavation of river bed along the banks for sand and gravel, dam building activities at the upper reaches of the rivers all may be responsible for the lack of the overall diversity of this threatened and ornamental fish species in this region. Therefore, conservational interventions may be directed towards the Terai population. Proper steps should be taken to improve the environment to avoid further losses. The genetic data obtained from the present study lend support to the view that there is a scope of stock improvement for this threatened ornamental fish.

\section{Conflict of Interests}

The authors declare that there is no conflict of interests regarding the publication of this paper.

\section{Acknowledgments}

The work was supported by a research grant from University Grants Commission (UGC), India (MRP Sanction no. 40289/2011 (SR)) awarded to corresponding author. The authors are thankful to the Department of Zoology, University of North Bengal, for providing necessary facility and Dr. Ranjan 
Roy, Department of Geography and Applied Geography, University of North Bengal, for providing help in cartography, as well as the freely distributed software applications.

\section{References}

[1] W. S. Lakra, U. K. Sarkar, A. Gopalakrishnan, and A. Kathirvelpandian, Threatened Freshwater Fishes of India, National Bureau of Fish Genetic Resources (NBFGR), Lucknow, India, 2010.

[2] R. Frankham, "Conservation genetics," Annual Review of Genetics, vol. 29, pp. 305-327, 1995.

[3] G. Caughley and A. Gunn, Conservation Biology in Theory and Practice, Blackwell Science, Cambridge, Mass, USA, 1996.

[4] J. C. Avise and J. L. Hamrick, Conservation and Genetics: Case Histories from Nature, Chapman \& Hall, New York, NY, USA, 1996.

[5] L. F. Landweber and A. P. Dobson, Genetics and the Extinction of Species: DNA and the Conservation of Biodiversity, Princeton University Press, Princeton, NJ, USA, 1999.

[6] S. Wang, J. J. Hard, and F. Utter, "Salmonid inbreeding: a review," Reviews in Fish Biology and Fisheries, vol. 11, no. 4, pp. 301-319, 2001.

[7] G. R. Carvalho, "Evolutionary aspects of fish distribution: genetic variability and adaptation," Journal of Fish Biology, vol. 43, pp. 53-73, 1993.

[8] J. Welsh and M. McClelland, "Fingerprinting genomes using PCR with arbitrary primers," Nucleic Acids Research, vol. 18, no. 24, pp. 7213-7218, 1990.

[9] J. G. K. Williams, A. R. Kubelik, K. J. Livak, J. A. Rafalski, and S. V. Tingey, "DNA polymorphisms amplified by arbitrary primers are useful as genetic markers," Nucleic Acids Research, vol. 18, no. 22, pp. 6531-6535, 1990.

[10] H. Hadrys, M. Balick, and B. Schierwater, "Applications of random amplified polymorphic DNA (RAPD) in molecular ecology," Molecular Ecology, vol. 1, no. 1, pp. 55-63, 1992.

[11] A. P. Wasko and P. M. Galetti Jr., "RAPD analysis in the Neotropical fish Brycon lundii: genetic diversity and its implications for the conservation of the species," Hydrobiologia, vol. 474, pp. 131137, 2002.

[12] M. S. P. Leuzzi, F. S. de Almeida, M. L. Orsi, and L. M. K. Sodré, "Analysis by RAPD of the genetic structure of Astyanax altiparanae (Pisces, Characiformes) in reservoirs on the Paranapanema River, Brazil," Genetics and Molecular Biology, vol. 27, no. 3, pp. 355-362, 2004.

[13] T. Hatanaka and P. M. Galetti Jr., "RAPD markers indicate the occurence of structured populations in a migratory freshwater fish species," Genetics and Molecular Biology, vol. 26, no. 1, pp. 19-25, 2003.

[14] F. You, P. Zhang, K. Wang, and J. Xiang, "Genetic variation of natural and cultured stocks of Paralichthys olivaceus by allozyme and RAPD," Chinese Journal of Oceanology and Limnology, vol. 25, no. 1, pp. 78-84, 2007.

[15] M. S. Islam and M. S. Alam, "Randomly amplified polymorphic DNA analysis of four different populations of the Indian major carp, Labeo rohita (Hamilton)," Journal of Applied Ichthyology, vol. 20, no. 5, pp. 407-412, 2004.

[16] R. K. Garg, N. Silawat, P. Sairkar, N. Vijay, and N. N. Mehrotra, "RAPD analysis for genetic diversity of two populations of Mystus vittatus (Bloch) of Madhya Pradesh, India," African Journal of Biotechnology, vol. 8, no. 17, pp. 4032-4038, 2009.
[17] R. K. Garg, P. Sairkar, N. Silawat, N. Batav, and N. N. Mehrotra, "Assessment of genetic diversity of Clarias batrachus using RAPD markers in three water bodies of Bhopal," Journal of Environmental Biology, vol. 31, no. 5, pp. 749-753, 2010.

[18] M. S. Alam, M. S. Islam, and M. S. Alam, "DNA fingerprinting of the freshwater Mud Eel, Monopterus cuchia (Hamilton) by randomly amplified polymorphic DNA (RAPD) marker," International Journal of Biotechnology and Biochemistry, vol. 6, no. 2, pp. 271-278, 2010.

[19] P. R. A. M. Affonso and P. M. Galetti Jr., "Genetic diversity of three ornamental reef fishes (Families Pomacanthidae and Chaetodontidae) from the Brazilian coast," Brazilian Journal of Biology, vol. 67, no. 4, pp. 925-933, 2007.

[20] P. Amavet, J. C. Vilardi, E. Rosso, and B. Saidman, "Genetic and morphometric variability in caiman latirostris (broad-snouted caiman), reptilia, alligatoridae," Journal of Experimental Zoology Part A: Ecological Genetics and Physiology, vol. 311, no. 4, pp. 258-269, 2009.

[21] K. A. Prior, H. L. Gibbs, and P. J. Weatherhead, "Population genetic structure in the black rat snake: implications for management," Conservation Biology, vol. 11, no. 5, pp. 1147-1158, 1997.

[22] M. P. Brahmane, M. K. Das, M. R. Sinha et al., "Use of RAPD fingerprinting for delineating populations of hilsa shad Tenualosa ilisha (Hamilton, 1822)," Genetics and Molecular Research, vol. 5, no. 4, pp. 643-652, 2006.

[23] F. Bardakci and D. O. F. Skibinski, "Application of the RAPD technique in tilapia fish: species and subspecies identification," Heredity, vol. 73, no. 2, pp. 117-123, 1994.

[24] M. P. Brahmane, K. Mitra, and S. S. Mishra, "RAPD fingerprinting of the ornamental fish Badis badis (Hamilton 1822) and Dario dario (Kullander and Britz 2002) (Perciformes, Badidae) from West Bengal, India," Genetics and Molecular Biology, vol. 31, no. 3, pp. 789-792, 2008.

[25] Y. Yamazaki, N. Fukutomi, N. Oda, K. Shibukawa, Y. Niimura, and A. Iwata, "Occurrence of larval Pacific lamprey Entosphenus tridentatus from Japan, detected by random amplified polymorphic DNA (RAPD) analysis," Ichthyological Research, vol. 52, no. 3, pp. 297-301, 2005.

[26] P. K. Talwar and A. G. Jhingran, Inland Fishes of India and Adjacent Countries, Oxford \& IBH, New Delhi, India, 1991.

[27] T. Mukhopadhyay and S. Bhattacharjee, "Standardization of genomic DNA isolation from minute quantities of fish scales and fins amenable to RAPD-PCR," Proceedings of Zoological Society, vol. 67, pp. 28-32, 2014.

[28] M. Lynch and B. G. Milligan, "Analysis of population genetic structure with RAPD markers," Molecular Ecology, vol. 3, no. 2, pp. 91-99, 1994.

[29] F. C. Yeh, R. C. Yang, T. B. J. Boyle, Z. H. Ye, and J. X. Mao, POPGENE Version 1.32, the User-Friendly Shareware for Population Genetic Analysis, Molecular Biology and Biotechnology Centre, University of Alberta, Edmonton, Canada, 1999, http://www.ualberta.ca/ fyeh/.

[30] M. P. Miller, “Tools for population genetic analysis (TFPGA) 1.3: a windows program for the analysis of allozyme and molecular population genetic data," Computer software distributed by author, 1997.

[31] R. Peakall and P. E. Smouse, "GENALEX 6: genetic analysis in Excel. Population genetic software for teaching and research," Molecular Ecology Notes, vol. 6, no. 1, pp. 288-295, 2006.

[32] R. Peakall and P. E. Smouse, "GenALEx 6.5: genetic analysis in Excel. Population genetic software for teaching and researchan update," Bioinformatics, vol. 28, no. 19, pp. 2537-2539, 2012. 
[33] M. Kimura and J. F. Crow, "The number of alleles that can be maintained in a finite population," Genetics, vol. 49, pp. 725738, 1964.

[34] M. Nei, "Analysis of gene diversity in subdivided populations," Proceedings of the National Academy of Sciences of the United States of America, vol. 70, no. 12, pp. 3321-3323, 1973.

[35] R. C. Lewontin, "The apportionment of human diversity," Evolutionary Biology, vol. 6, pp. 381-398, 1972.

[36] S. Wright, Evolution and the Genetics of Populations, University of Chicago Press, Chicago, Ill, USA, 1969.

[37] H. Fuchs, R. Gross, H. Stein, and O. Rottmann, "Application of molecular genetic markers for the differentiation of bream (Abramis brama L.) populations from the rivers Main and Danube," Journal of Applied Ichthyology, vol. 14, no. 1-2, pp. 4955, 1998.

[38] H. A. M. A. Kader, Z. G. A. Hamid, and K. F. Mahrous, "Genetic diversity among three species of Tilapia in Egypt detected by random amplified polymorphic DNA marker," Journal of Applied Biological Science, vol. 7, no. 2, pp. 57-64, 2013.

[39] G. Chandra, A. Saxena, and A. Barat, "Genetic diversity of two riverine populations of Eutropiichthys vacha (Hamilton, 1822) using RAPD markers and implications for its conservation," Journal of Cell and Molecular Biology, vol. 8, no. 2, pp. 77-85, 2010.

[40] M. F. Miah, P. Guswami, R. Al Rafi et al., "Assessment of genetic diversity among individuals of freshwater Mud Eel, Monopterus cuchia in a population of Bangladesh," American International Journal of Research in Science, Technology, Engineering \& Mathematics, vol. 3, no. 2, pp. 176-181, 2013.

[41] P. M. Abdul Muneer, A. Gopalakrishnan, K. K. Musammilu et al., "Genetic variation and population structure of endemic yellow catfish, Horabagrus brachysoma (Bagridae) among three populations of Western Ghat region using RAPD and microsatellite markers," Molecular Biology Reports, vol. 36, no. 7, pp. 1779-1791, 2009.

[42] G. D. Khedkar, A. C. S. Reddy, P. Mann, K. Ravinder, and K. Muzumdar, "Clarias batrachus (Linn.1758) population is lacking genetic diversity in India," Molecular Biology Reports, vol. 37, no. 3, pp. 1355-1362, 2010.

[43] J. Welsh, C. Petersen, and M. McClelland, "Polymorphisms generated by arbitrarily primed PCR in the mouse: application to strain identification and genetic mapping," Nucleic Acids Research, vol. 19, no. 2, pp. 303-306, 1991.

[44] W. Mwanja, G. C. Booton, L. Kaufman, M. Chandler, and P. A. Fuerst, "Population and stock characterization of Lake Victoria tilapine fishes based on RAPD markers," in Aquaculture Biotechnology, Symposium Proceedings, International Congress on the Biology of Fishes, E. M. Donaldson and D. D. MacKinlay, Eds., pp. 115-124, American Fisheries Society, 1996.

[45] S. A. Appleyard and P. B. Mather, "Genetic characterization of cultured Tilapia in Fiji using Allozyme and Random Amplified polymorphic DNA," Asian Fisheries Science, vol. 15, pp. 249-265, 2002.

[46] M. J. Kaiser, K. Ramsay, C. A. Richardson, F. E. Spence, and A. R. Brand, "Chronic fishing disturbance has changed shelf sea benthic community structure," Journal of Animal Ecology, vol. 69, no. 3, pp. 494-503, 2000.

[47] F. W. Allendorf, G. Luikart, and S. N. Aitken, Conservation and the Genetics of Populations, John Wiley \& Sons, London, UK, 2013. 

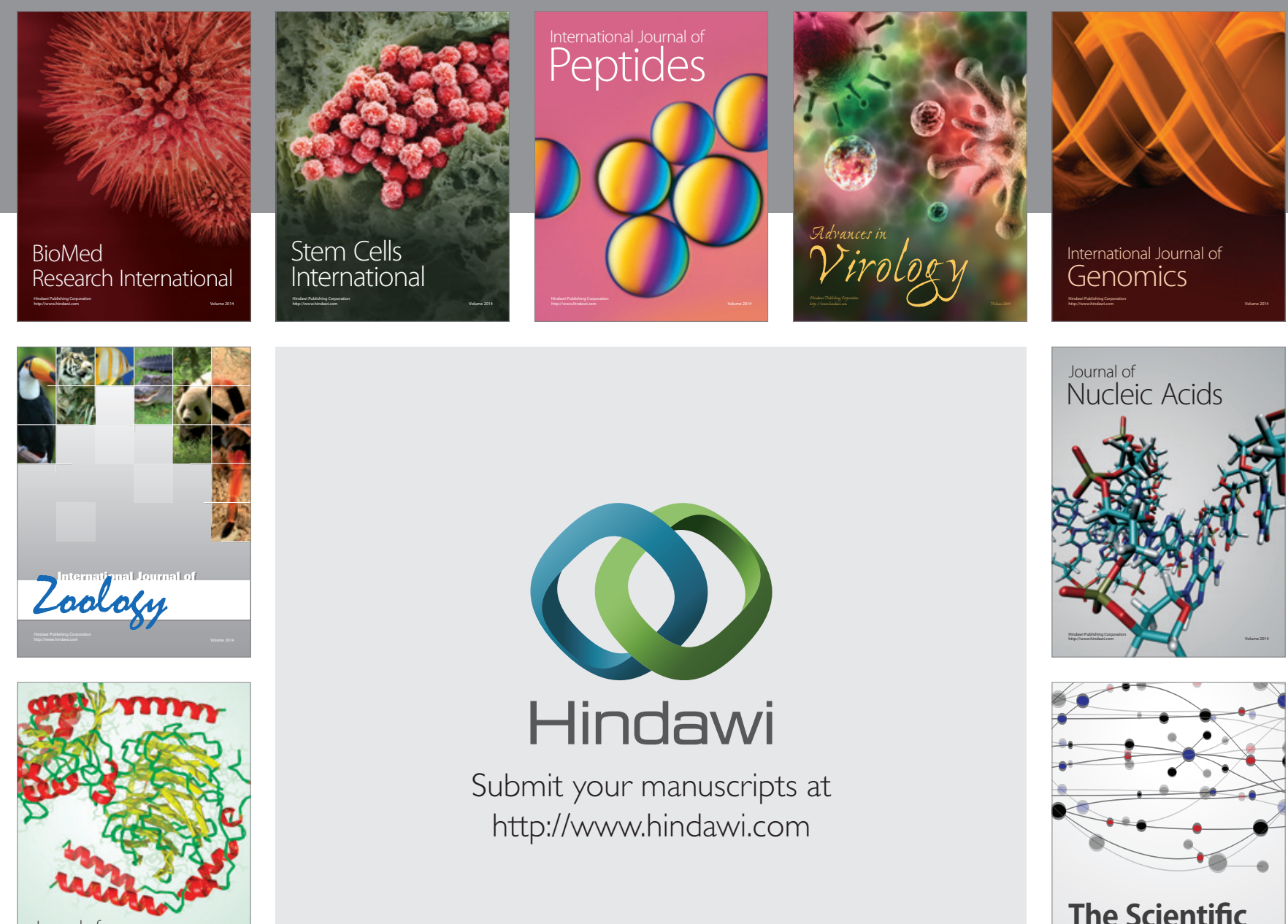

Submit your manuscripts at

http://www.hindawi.com

Journal of
Signal Transduction
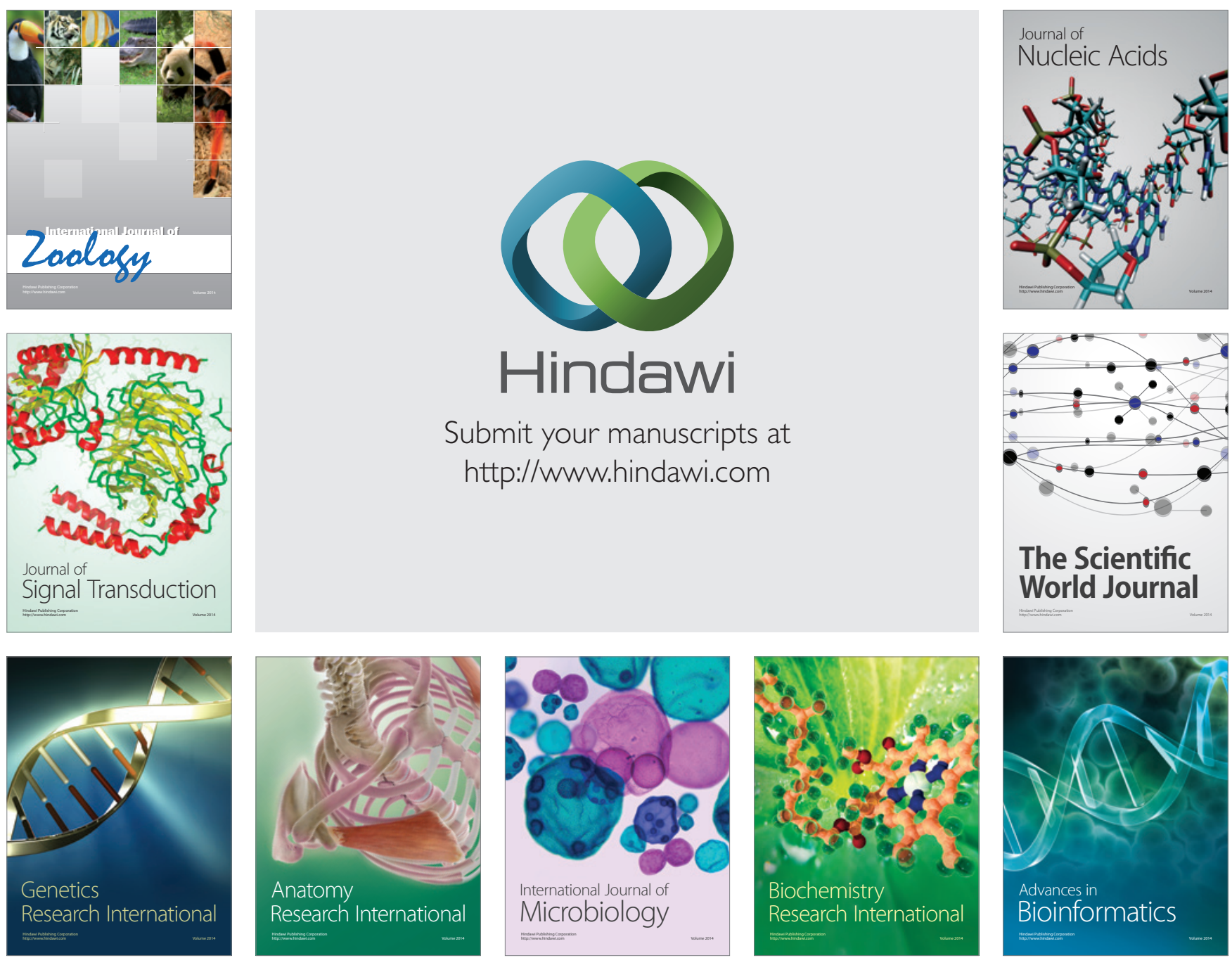

The Scientific World Journal
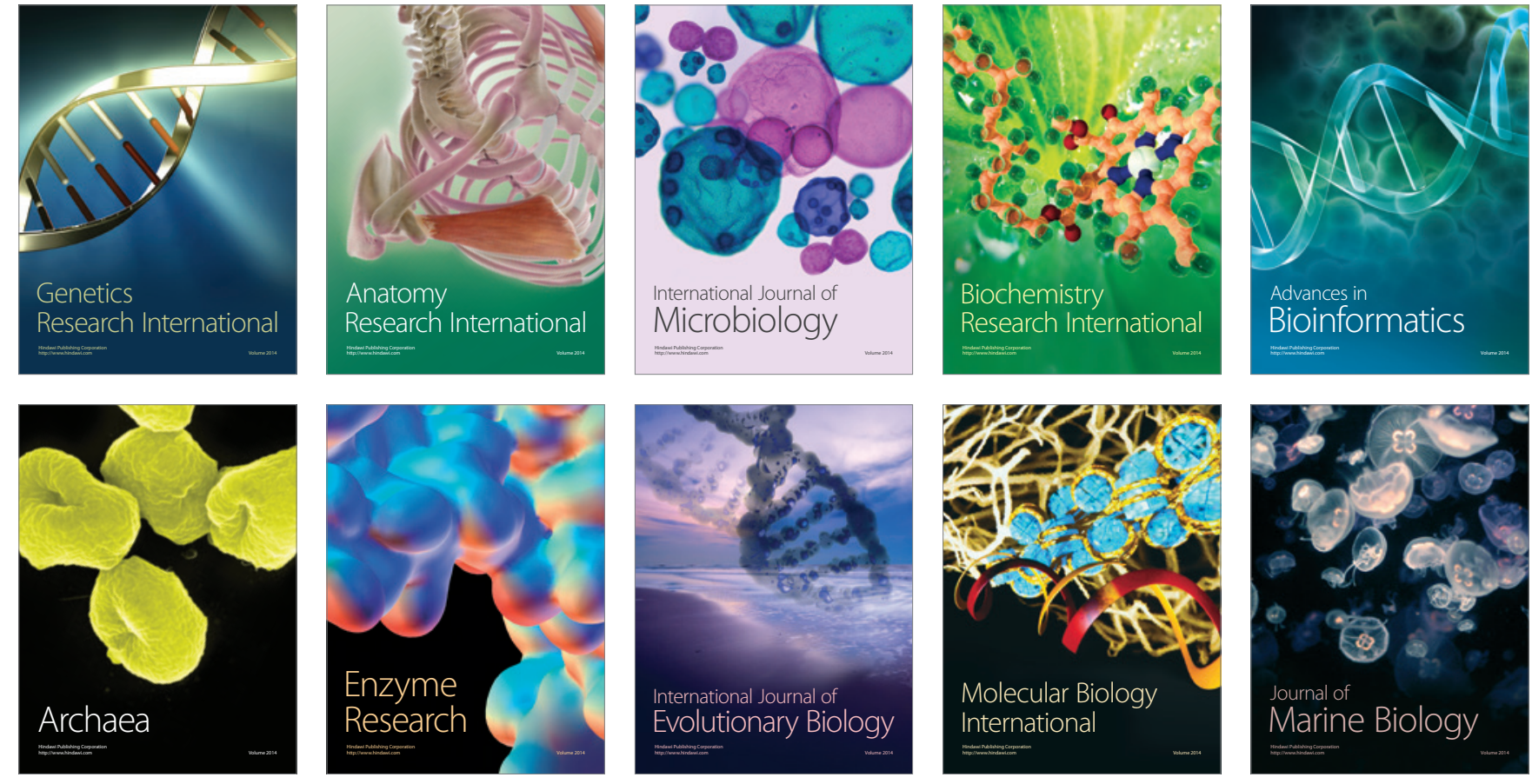